\title{
Distinct long-term regulation of glycerol and non-esterified fatty acid release by insulin and TNF- $\alpha$ in 3T3-L1 adipocytes
}

\author{
M. Rosenstock ${ }^{1}$, A.S. Greenberg ${ }^{2}$, A. Rudich ${ }^{1}$ \\ ${ }^{1}$ The S. Daniel Abraham Center for Health and Nutrition, Department of Clinical Biochemistry, Faculty of Health Sciences, \\ Ben-Gurion University of the Negev, Beer-Sheva, Israel \\ ${ }^{2}$ The Jean Mayer USDA Human Nutrition Research Center on Aging at Tufts University, Boston, Massachusetts, USA
}

\section{Abstract}

Aims/hypothesis. Adipose tissue lipolysis plays a central part in total body fuel metabolism. Our study was to assess the long-term regulation of glycerol and non-esterified fatty acid (NEFA) release by insulin or TNF- $\alpha$.

Methods. Fully differentiated 3T3-L1 adipocytes were exposed for up to $22 \mathrm{~h}$ to insulin or TNF- $\alpha$.

Results. Long-term insulin treatment resulted in increased basal glycerol release, reaching sixfold at $22 \mathrm{~h}$ with $1 \mathrm{nmol} / \mathrm{l}$ insulin. Partial inhibition was observed by pharmacologically inhibiting phosphatidylinositol 3-kinase or the mitogen-activated kinase kinase - extracellular signal-regulated kinase cascades. This represented $50-60 \%$ of the response induced by $1 \mathrm{nmol} / 1 \mathrm{TNF}-\alpha$ and approximately $40 \%$ of the glycerol release maximally stimulated by isoproterenol $(1 \mu \mathrm{mol} / 1,30 \mathrm{~min})$. The cellular mechanism seemed to be distinct from that of TNF- $\alpha$ : First, glycerol release in response to long-term insulin was progressive with time and did not display a lag-time char- acteristic of the effect of TNF- $\alpha$. Second, pretreatment and co-treatment of the cells with troglitazone greatly inhibited TNF- $\alpha$-induced glycerol release $(128.5 \pm 10.2$ to $35.4 \pm 2.1 \mathrm{nmol} / \mathrm{mg}$ protein per $\mathrm{h})$ but not the effect of insulin, which was exaggerated. Third, hormone-sensitive lipase protein content was decreased $(45 \%)$ by TNF- $\alpha$ but not following longterm insulin. Finally, TNF- $\alpha$ was associated with NEFA release to the medium, whereas long-term insulin treatment was not. Moreover, glycerol release during isoproterenol-stimulated lipolysis was additive to the effect of long-term insulin, whereas NEFA release was inhibited by nearly $90 \%$.

Conclusions interpretation. Contradictory to its shortterm inhibitory effect, long-term insulin stimulates glycerol release with concomitant stimulation of NEFA re-esterification. [Diabetologia (2001) 44: 5562]

Keywords Lipolysis, troglitazone, long-term insulin, hormone sensitive lipase.
The regulation of adipocyte lipolysis is increasingly recognized to play a part in the pathophysiology of

Received: 22 May 2000 and in revised form: 16 August 2000

Corresponding author: A. Rudich, MD, PhD, Department of Clinical Biochemistry, Faculty of Health Sciences, Ben-Gurion University of the Negev, Beer-Sheva, IL-84105, Israel

Abbreviations: ERK, Extracellular signal-regulated kinase 1/2; HSL, hormone-sensitive lipase; LPL, lipoprotein lipase; MEK, mitogen-activated kinase kinase ; PKA, protein kinase A; PI 3kinase phosphatidylinositol 3 kinase; TZD, thiazolidinedione; PDE-3B, phosphodiesterase 3B; KRP, Krebs-Ringer phosphate; RIA, radioimmunoassay. obesity, insulin resistance and Type II (non-insulindependent) diabetes mellitus. Both non-esterified fatty acids (NEFA) and glycerol, the two end products of lipolysis, are potential mediators for metabolic (dys)regulation, which is associated with these common conditions [1,2]. Prolonged increases in NEFA concentrations could induce or aggravate skeletal muscle insulin resistance [3], impair pancreatic betacell function [4] and result in glucose overproduction $[5,6]$. Glycerol has recently been suggested to be used by skeletal muscle as a precursor for intra-muscular triacylglycerol synthesis [2], which in turn when excessive, could result in skeletal muscle insulin 
resistance [7]. Consistent with this is the increased basal lipolysis $[5,8]$ and the altered catacholaminestimulated lipolysis $[8,9]$ seen in cohorts of Type II diabetic and obese patients, further supporting the involvement of altered NEFA and glycerol generation in these pathophysiological conditions. The mechanisms for these abnormalities in both short-term and long-term regulation of adipocyte lipolysis have, however, not been fully resolved.

Beta-adrenergic agents and insulin are important short-term regulators of lipolysis, largely through protein kinase A (PKA)-mediated phosphorylation of hormone-sensitive lipase (HSL) [10-12]. This enzyme has been extensively studied and is considered the major regulatory and rate-limiting enzyme in adipocyte triacylglycerol breakdown [13-15]. Although beta-adrenergic agents stimulate PKA, short-term insulin treatment inhibits HSL activity through the stimulation of phosphodiesterase 3B (PDE-3B) which occurs in a phosphatidylinositol 3-kinase dependent manner [16-19]. Complementarily, insulin stimulates the re-esterification of NEFA to triglycerides in the short term [20-22], providing an additional mechanism for inhibiting NEFA release from adipose tissue.

Long-term regulatory mechanisms of adipocyte lipolysis are less well characterized. Of the various factors suggested to play a part in impaired adipocyte function in insulin resistance and diabetes, increased TNF- $\alpha$ expression and production and long-term exposure to high circulating insulin concentrations have attracted interest. It has been shown that TNF$\alpha$ is produced and excreted from adipose tissue in obesity and thus acts in an autocrine fashion to alter adipocyte function [23, 24]. Long-term exposure ( $>6 \mathrm{~h}$ ) to TNF- $\alpha$ has been shown to stimulate lipolysis in adipocytes $[25,26]$, despite inducing reduced HSL expression [27, 28]. Several cellular mechanisms have been suggested to explain this effect of TNF- $\alpha$ on adipocyte lipolysis. Among them that lower levels of expression of inhibitory $\mathrm{G}$ proteins, induced in adipocytes by TNF- $\alpha$ treatment, reduces the tonic basal inhibition of lipolysis rate [29]. Another explanation has been the TNF- $\alpha$-induced reduction in the expression of perilipin [30], a protein suggested to play a part in regulating HSL access to intracellular triacylglycerol $[31,32]$. This effect of TNF- $\alpha$, as well as the activation of lipolysis, was prevented by thiazolidinediones [28], a class of insulin sensitizing anti-diabetic agents [33]. A recent study suggested that TNF- $\alpha$ reduced the expression of PDE-3B, which resulted in increased PKA activity and thus, enhanced HSL phosphorylation and activity [34].

The possibility that long-term exposure to insulin stimulates glycerol release from adipocytes as opposed to its short-term anti-lipolytic effect is less well established. Two studies in which primary adipocytes were used suggested either enhanced HSL ac- tivity [35] or alteration in its cellular localization [36] as an underling mechanism. An earlier study in 3T3L1 adipocytes indicated a correlation between enhanced glycerol release induced by long-term insulin treatment and activation of lipoprotein lipase (LPL) [37], an enzyme generally considered to function in the vasculature on triacylglycerol stored in lipoproteins, rather than on intracellular triacylglycerol pools [38].

In our study we compared the effect of long-term exposure of 3T3-L1 adipocytes to TNF- $\alpha$ or to insulin, on glycerol and NEFA release, which enabled us to assess their effect on both lipolysis and re-esterification. In addition, we investigated whether the thiazolidinedione (TZD) troglitazone can inhibit longterm insulin-induced lipolysis, as was shown for TNF- $\alpha$. Our findings indicate that the long-term regulation of lipolysis by TNF- $\alpha$ and insulin occurs through seemingly distinct mechanisms, with TZDs preventing the former but enhancing the latter.

\section{Materials and methods}

Cell culture and treatments. The 3T3-L1 adipocytes (American Type Tissue Culture Collection, Manassas, Va., USA) were grown in high glucose $(25 \mathrm{mmol} / \mathrm{l})$ Dulbecco's modified Eagle's medium (DMEM, Biological Industries, Beit-Haemek, Israel) and differentiated exactly as described previously [39, 40]. Fully differentiated cells were incubated with serum free DMEM supplemented with $0.5 \%$ radioimmunoassay (RIA) grade bovine serum albumin (BSA, Sigma Chemical Co., St. Louis, Mo., USA) and with either recombinant human insulin (Novo-Nordisk, Bagsvaerd, Denmark) or TNF- $\alpha$ (kindly provided by Dr. P. H. Pekala, East Carolina University, Greenville, N.C., USA). For pretreatment and co-treatment with troglitazone or an inactive TZD $(10 \mu \mathrm{mol} / \mathrm{l}$ each, kindly provided by Drs. A. Saltiel and H. Camp, Parke-Davis, Ann-Arbor, Mich., USA), cells were incubated in full DMEM for $6 \mathrm{~h}$ before and then in serum free medium during insulin or TNF- $\alpha$ treatments, as described above. Cell viability was monitored by protein recovery, 3-[4,5-dimethylthiazol-2-yl]-2,5-diphenyltetrazolium bromide (MTT) test and lactate dehydrogenase release to the medium.

Hexose transport measurements. The uptake of 2-deoxyglucose was done exactly as described previously [39, 41], using $50 \mu \mathrm{mol} / \mathrm{l} 2$ 2-deoxy- $\left[{ }^{3} \mathrm{H}\right]$-glucose (Nuclear Research Center, Dimona, Israel) $\left(3.7 \cdot 10^{4} \mathrm{~Bq} / \mathrm{ml}\right)$ for $10 \mathrm{~min}$.

Lipolysis measurements. Lipolysis was measured by assessing glycerol and NEFA release at the end of a 22-h incubation without or with insulin or TNF- $\alpha$. Cells were rinsed three times with PBS and further incubated with Krebs-Ringer phosphate (KRP) buffer (HEPES $50 \mathrm{mmol} / \mathrm{l} \mathrm{pH} \mathrm{7.4,} \mathrm{NaCl} 128 \mathrm{mmol} / \mathrm{l}$, $\mathrm{KCl} 4.7 \mathrm{mmol} / \mathrm{l}, \mathrm{CaCl}_{2} 1.25 \mathrm{mmol} / \mathrm{l}, \mathrm{MgSO}_{4} 1.25 \mathrm{mmol} / \mathrm{l}$ and sodium phosphate $10 \mathrm{mmol} / \mathrm{l})$ supplemented with $1 \%$ RIA grade BSA (results were compared and found to be identical with non-esterified fatty acid-free BSA supplemented buffer). Non-esterified fatty acid concentrations were measured using a commercial kit (Roche, Mannheim, Germany) following the instructions of the manufacturer and calculated according to an oleic acid standard curve done in the same buffer. Glycerol 
A

IRS-1

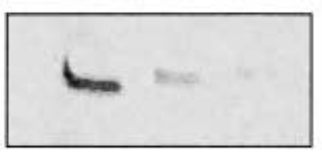

GLUT4

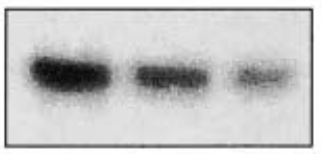

long-term insulin (nmol/l)

$\begin{array}{lll}0 & 0.1 & 1\end{array}$

B

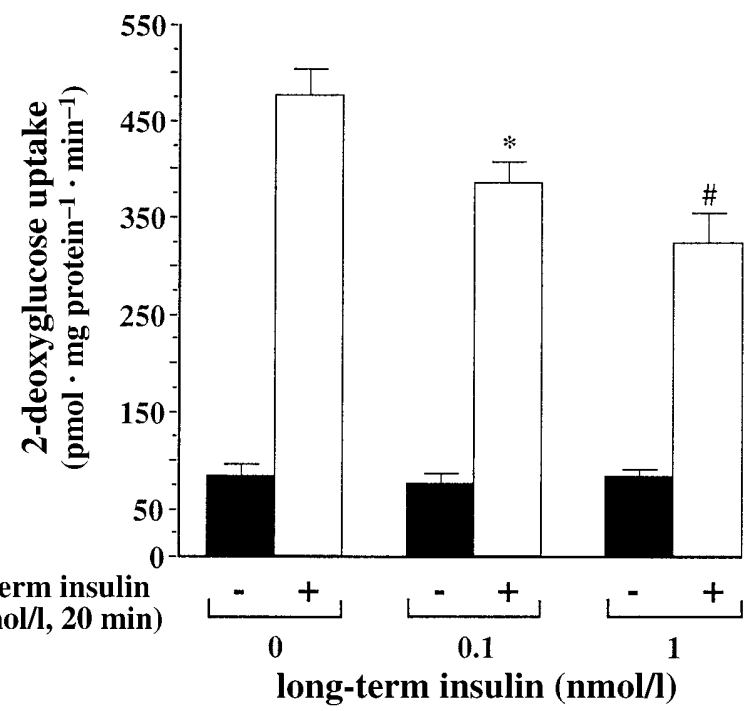

Fig.1 A, B. Prolonged exposure of 3T3-L1 adipocytes to insulin induces insulin resistance. A Western blots of total membranes using anti-IRS-1 or anti-GLUT4 antibodies, representative of 3 independent experiments. B 2-deoxyglucose measurements $[(\boldsymbol{\square})$ Basal, $(\square)$ following 20-min stimulation with $100 \mathrm{nmol} / \mathrm{l}$ insulin] are presented as means \pm SEM of five independent experiments done at least in duplicates. $* p \leq 0.05$ compared with insulin stimulated control cells. \# $p \leq 0.005$ compared with insulin-stimulated control cells

was measured spectrophotometrically using glycerokinase and glycerol phosphate dehydrogenase (both from Sigma), as described [42]. Glycerol and NEFA release were linear for at least $2 \mathrm{~h}$. Thus, for basal lipolysis rates 1-h incubation in KRP was used and maximally stimulated lipolysis using $1 \mu \mathrm{mol} / \mathrm{l}$ isoproterenol was done for $30 \mathrm{~min}$. Fractional re-esterification was calculated as previously described [22], based on the knowledge that glycerol cannot be used to any great extent by adipocyte [43] and that NEFA are mainly used by re-esterification $[22,44]$. Primary NEFA generation occurs at a 1:3, glycerol:NEFA ratio and thus the fractional NEFA re-esterification is calculated as: $[(3 \times$ glycerol released-measured NEFA released) $/ 3 \cdot$ glycerol released] $\times 100$. This value can vary from 0 to $100 \%$, i.e. no re-esterification at all or complete re-esterification, respectively.

Cell lysates, total membranes and western blots. Cells (1-2 wells of a 6-well plate for each condition) were rinsed three times with PBS. Cell lysates were prepared by adding $0.25 \mathrm{ml}$ of high SDS buffer per well, as we described [28]. Total membranes were prepared after homogenization of the cells in $250 \mathrm{mmol} / 1$ sucrose, $20 \mathrm{mmol} / 1 \mathrm{HEPES} \mathrm{pH} 7.4,1 \mathrm{mmol} / 1$
EDTA, $0.2 \mathrm{mmol} / 1$ sodium vanadate and protease inhibitors as listed above. Western blot analysis of either $15 \mu \mathrm{g}$ cell lysate protein (measured using BCA method, Pierce, Rockford, IL., USA) or $10 \mu \mathrm{g}$ total membrane protein (measured using BioRad reagent, Bio-Rad Laboratories, Munchen, Germany) were done as described previously [40, 41]. The IRS-1, GLUT4 and HSL protein content were detected using antiIRS-1 antibody (Upstate Biotechnology, Lake Placid, N. Y., USA), anti-GLUT4 antibody (Chemicon, Temecula, Calif., USA) and an anti-HSL antibody [28], respectively.

Statistical analysis. The student's $t$ test was used for comparing values of two groups. We considered a $p$ value of 0.05 to be the limit for statistical significance.

\section{Results}

Fully differentiated 3T3-L1 adipocytes were exposed for $22 \mathrm{~h}$ to either insulin or TNF- $\alpha$, at a concentration range of $0.01-1 \mathrm{nmol} / \mathrm{l}$. Cells were incubated in serum free medium with up to $1 \mathrm{nmol} / 1 \mathrm{TNF}-\alpha$, because TNF- $\alpha$ concentrations above $5 \mathrm{nmol} / \mathrm{l}$ were associated with a statistically significant reduction in cell viability (assessed as described in Methods). The TNF$\alpha$ treatment up to $1 \mathrm{nmol} / \mathrm{l}$ and for up to $22 \mathrm{~h}$ was not associated with statistically significant alterations in basal or in insulin-stimulated glucose transport activity (data not shown). For long-term insulin treatment, this concentration range was preferred to the higher $100-1000 \mathrm{nmol} / \mathrm{l}$ used in most studies [45, 46]. The sub-nmol/l range better represents physiological and supra-physiological circulating insulin concentrations measured in vivo. In addition, in 3T3-L1 adipocytes, this range of insulin concentrations induces insulin but not IGF-1 receptor-mediated signalling [47]. To control for statistically significant degradation of insulin during the 22-h incubation [48], the medium was transferred at the end of the incubation to untreated cells and the short-term insulin effect on glucose transport was measured. Insulin activity in the medium was similar to that of a medium to which freshly prepared insulin has been added (data not shown) at both 0.1 and $1 \mathrm{nmol} / \mathrm{l}$, suggesting that the cells were exposed to stable insulin concentrations during the entire incubation.

Exposure of 3T3-L1 adipocytes to 0.1 and $1 \mathrm{nmol} / 1$ insulin for $22 \mathrm{~h}$ resulted in significantly decreased insulin-stimulated glucose transport activity (Fig.1). This was associated with reduced total membrane protein content of IRS-1 and GLUT4. These findings are consistent with previous studies, most $[45,46]$ but not all [48] of which used higher insulin concentrations.

Long-term insulin and TNF- $\alpha$ induce glycerol release from 3T3-L1 adipocytes. Dose and time effect of TNF- $\alpha$ and insulin on basal (non-stimulated) rates of glycerol release are shown in Figure 2. Long-term ex- 

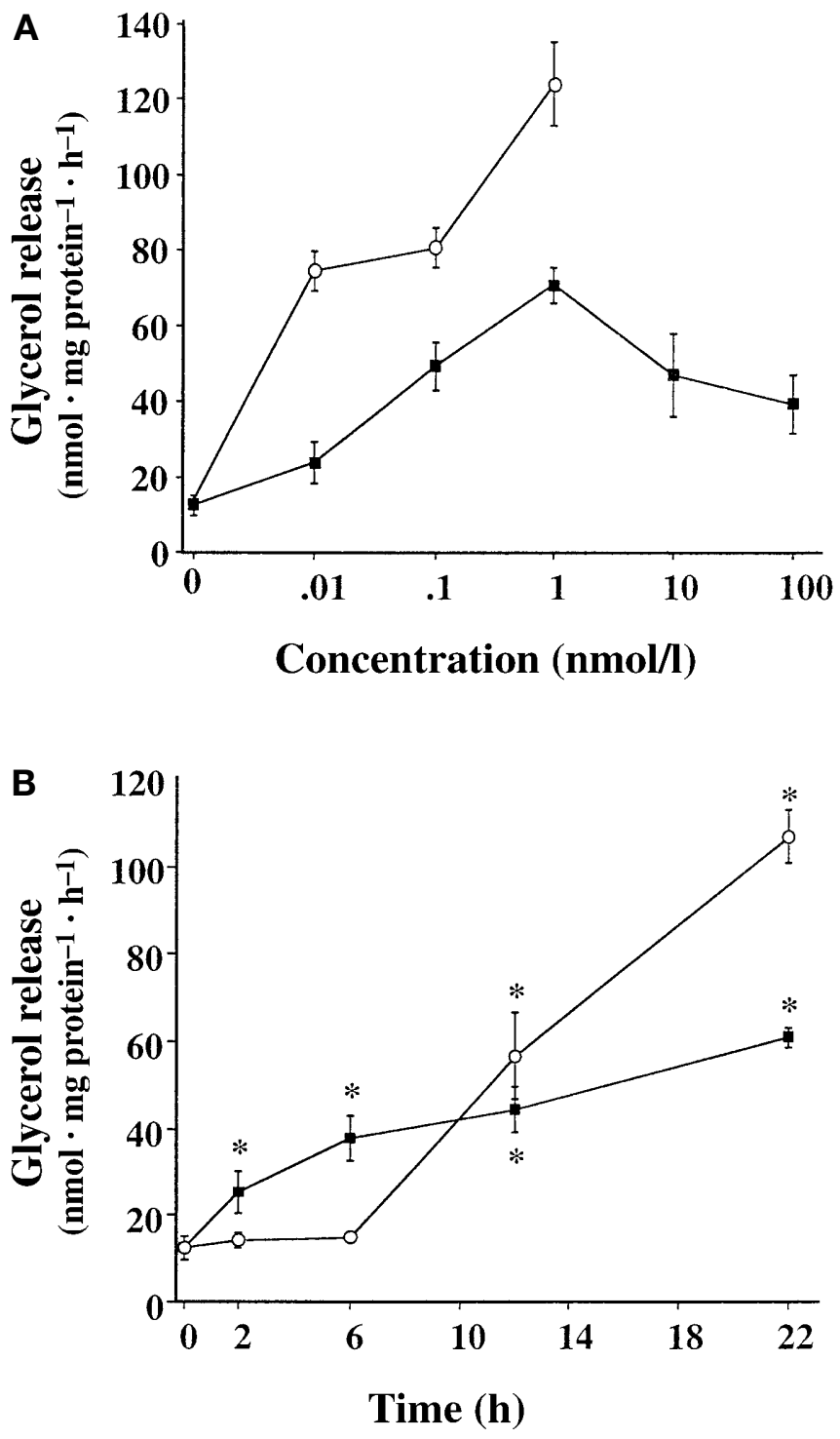

C

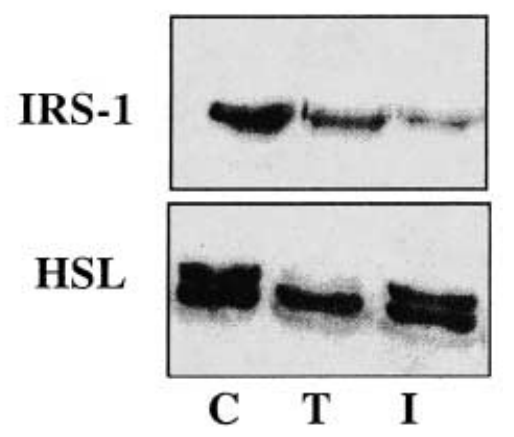

Fig. 2. A Dose response of 22-h incubation of 3T3-L1 adipocytes with either insulin ( $\square)$ or TNF- $\alpha(\bigcirc)$ on glycerol release. All points are significantly different $(p \leq 0.05)$ compared with the control, untreated value. B Time course of the stimulation of glycerol release by $1 \mathrm{nmol} / \mathrm{l}$ insulin ( $\boldsymbol{\square}$ ) or $1 \mathrm{nmol} / \mathrm{l} \mathrm{TNF}-\alpha$ (○). * $p \leq 0.05$ compared with basal glycerol release of untreated cells. Each value is the mean \pm SEM of at least three independent experiments done at least in duplicate. C The effect of $22 \mathrm{~h}$ of treatment with either $1 \mathrm{nmol} / 1 \mathrm{TNF}-\alpha \mathbf{( T )}$ or $1 \mathrm{nmol} / \mathrm{l}$ insulin (I) on protein content of IRS- 1 and HSL as assessed in total cell lysates and compared with untreated cells (C). Shown are blots representative of six independent experiments posure to insulin resulted in increased glycerol release to the medium, with the maximum effect observed with $1 \mathrm{nmol} / \mathrm{l}$ insulin (sixfold over basal value), although significant effects could be observed with concentrations as low as $0.01 \mathrm{nmol} / \mathrm{l}$. The time-course for stimulation of glycerol release shows that the lipolytic effect of TNF- $\alpha$ has a lag period of at least $6 \mathrm{~h}$. In contrast, the stimulation of basal glycerol release by insulin was significant as early as after $2 \mathrm{~h}$ of incubation and increased progressively up to $22 \mathrm{~h}$. At this point, glycerol release rate in cells incubated with $1 \mathrm{nmol} / \mathrm{l}$ insulin was typically $50-60 \%$ of the value obtained with $1 \mathrm{nmol} / 1 \mathrm{TNF}-\alpha$ and represented $40 \%$ of the maximally stimulated glycerol release achieved after 30 -min incubation with $1 \mu \mathrm{mol} / \mathrm{l}$ isoproterenol (Fig. 3).

Pharmacological inhibitors of several components of the insulin signal were used to find the signalling cascades involved in the induction of glycerol release by long-term insulin. The phosphatidylinositol $3 \mathrm{ki}-$ nase (PI 3-kinase) inhibitor, Ly 294002 (100 $\mu \mathrm{mol} / \mathrm{l})$, and the mitogen-activated kinase kinase (MEK) inhibitor, PD $98059(50 \mu \mathrm{mol} / \mathrm{l})$ were added $15 \mathrm{~min}$ before and during incubation with insulin for $9 \mathrm{~h}$. Glycerol release was reduced from $66.6 \pm 2.5 \mathrm{nmol} \cdot \mathrm{mg}$ protein $^{-1} \cdot \mathrm{h}^{-1}$ to $41.7 \pm 3.0$ and $47.4 \pm 3.2$ by the PI 3kinase and the MEK inhibitors, respectively $(p<0.01$ for both values compared with the absence of inhibitors). In contrast, the mTOR - p70S6 kinase inhibitor rapamycin was without effect on glycerol release, even at concentrations of $200 \mathrm{ng} / \mathrm{ml}$. Taken together, these results suggest the involvement of both the PI 3-kinase and the MEK-extracelllular signalregulated kinase $1 / 2$ (ERK) cascades in mediating the induction of glycerol release by long-term insulin.

To assess whether the stimulation of glycerol release by TNF- $\alpha$ and long-term insulin is associated with changes in the protein content of HSL, total cell lysates were prepared. As previously shown [28], TNF- $\alpha$ treatment was associated with a decrease in the protein content of HSL as assessed in total cell lysates (Fig. 2). In contrast, long-term insulin was not associated with a statistically significant change in HSL protein content. Densitometry analysis of six independent experiments showed a non-statistically significant increase in HSL protein content in longterm insulin-treated cells, compared with control cells. For comparison, IRS-1 protein content in the same cell lysates is also shown. The distinct time course and effect on HSL expression, suggest that TNF- $\alpha$ and long-term insulin stimulate glycerol release through distinct cellular mechanisms.

To further investigate this notion, the effect of TNF- $\alpha$ and long-term insulin on NEFA release was assessed. Although TNF- $\alpha$ treatment stimulated 13fold NEFA release to the medium, with a time and dose dependency that paralleled glycerol release (not shown), no significant increase in NEFA release 


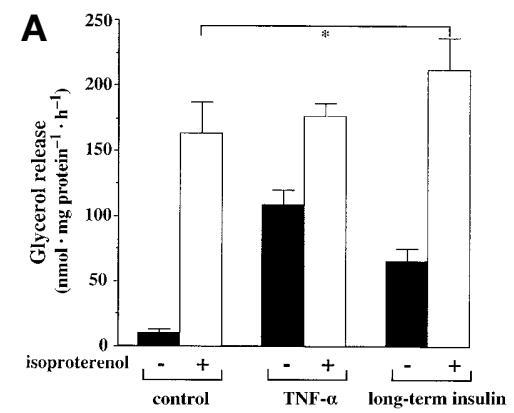

Fig. 3 A, B. The effect of TNF- $\alpha$ or long-term insulin treatment $(1 \mathrm{nmol} / \mathrm{l}, 22 \mathrm{~h})$ on basal $(\boldsymbol{\square})$ or isoproterenol stimulated (30 min, $1 \mu \mathrm{mol} / \mathrm{l})(\square)$ glycerol (A) or NEFA release (B) from 3T3-L1 adipocytes. Each value is the mean \pm SEM of three independent experiments done in triplicate. $* p \leq 0.05$. ** $p \leq 0.005$

could be observed after long-term insulin treatment (Fig. 3 B, Table 1). This discrepancy between glycerol and NEFA release was observed in all time and concentration ranges tested (not shown). The NEFA reesterification ratio after $22 \mathrm{~h}$ incubation with $1 \mathrm{nmol} /$ 1 TNF- $\alpha$ was calculated as the difference between the "primary" NEFA production $(3 \times$ glycerol $)$ and the actual NEFA measured, divided by the former, as described in "Materials and methods". Although overall NEFA re-esterification was typically below $30 \%$ in control cells and those treated with TNF- $\alpha$, long-term insulin treatment was associated with a large increase in the use of NEFA calculated (Table 1).

Long-term insulin alters the lipolytic response to betaadrenergic stimulation. To further establish that longterm insulin treatment stimulates lipolysis (as measured by glycerol release) while concomitantly stimulating NEFA re-esterification, the isoproterenol stimulated lipolysis was studied after long-term insulin or TNF- $\alpha$ treatments. Cells were incubated for $22 \mathrm{~h}$ with $1 \mathrm{nmol} / 1$ insulin or TNF- $\alpha$, rinsed and further incubated for $30 \mathrm{~min}$ with $1 \mu \mathrm{mol} / \mathrm{l}$ isoproterenol. Glycerol release stimulated by isoproterenol was not altered by $\mathrm{TNF}-\alpha$ pretreatment and NEFA release was nearly additive (Fig. 3). Notably, isoproterenolstimulated glycerol release added to the effect of

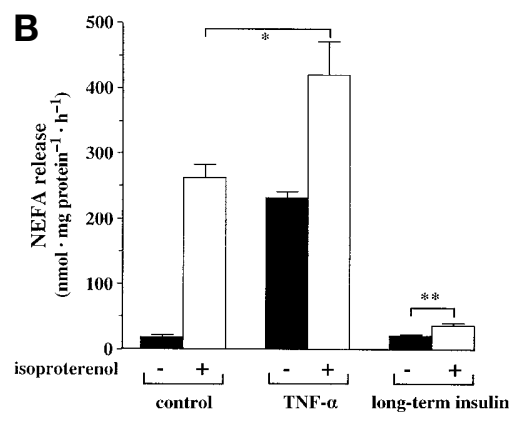

long-term insulin treatment, whereas the stimulation of NEFA release to the medium was greatly inhibited by insulin pretreatment.

Thiazolidinediones differently modulate the effects of long-term insulin compared with TNF on glycerol and NEFA release. The TZD troglitazone was recently shown to antagonize the lipolytic effect of TNF- $\alpha$. It prevented stimulation of glycerol and NEFA release, as well as the decreased protein content of HSL, which were induced by TNF- $\alpha$ treatment $[28,30]$. To gain further insight into the mechanism underlying the stimulation of glycerol release by long-term insulin compared with the effect of TNF- $\alpha, 3$ T3-L1 adipocytes were incubated with troglitazone and inactive TZD for $6 \mathrm{~h}$ before and during treatment with each agent, as described in "Materials and methods". Troglitazone treatment inhibited 70 and $95 \%$ of the glycerol and NEFA release induced by TNF- $\alpha$ treatment, respectively, whereas the inactive TZD was without effect on TNF- $\alpha$-induced lipolysis (Fig. 4). Conversely, troglitazone, which had no effect on glycerol or NEFA release in control cells, greatly exaggerated the effect of long-term insulin on glycerol release, without affecting NEFA release.

\section{Discussion}

In this study we show that long-term exposure of 3T3L1 adipocytes to insulin at and near physiological concentrations, results in increased basal glycerol release to the medium without a concomitant rise in NEFA release. These conditions also alter betaadrenergic-stimulated lipolysis, exaggerating glycerol but nearly preventing NEFA release. Finally, our

Table 1. Effect of TNF- $\alpha$ and long-term insulin on glycerol and NEFA release from 3T3-L1 adipocytes

\begin{tabular}{|c|c|c|c|}
\hline & $\begin{array}{l}\text { Glycerol release } \\
\left(\text { nmol }^{\prime} \mathrm{mg}_{\text {protein }}{ }^{-1} \cdot \mathrm{h}^{-1}\right)\end{array}$ & $\begin{array}{l}\text { NEFA release } \\
\left(\mathrm{nmol} \cdot \mathrm{mg}_{\text {protein }}{ }^{-1} \cdot \mathrm{h}^{-1}\right)\end{array}$ & $\begin{array}{l}\% \text { NEFA } \\
\text { Re-esterification }\end{array}$ \\
\hline control & $10.4 \pm 2.9$ & $17.7 \pm 3.3$ & $29.4 \pm 6.5$ \\
\hline TNF- $\alpha(1 \mathrm{nmol} / \mathrm{l}, 22 \mathrm{~h})$ & $108.3 \pm 11.7^{\mathrm{b}}$ & $231.4 \pm 9.5^{\mathrm{b}}$ & $25.2 \pm 2.4$ \\
\hline insulin $(1 \mathrm{nmol} / \mathrm{l}, 22 \mathrm{~h})$ & $64.8 \pm 10.4^{\mathrm{a}}$ & $20.8 \pm 1.9$ & $86.8 \pm 2.8^{\mathrm{a}}$ \\
\hline
\end{tabular}

Each value is the mean \pm SEM of three independent experiments done at least in duplicate. ${ }^{\mathrm{a}} p<0.01$ and ${ }^{\mathrm{b}} p<0.001$ compared with control 


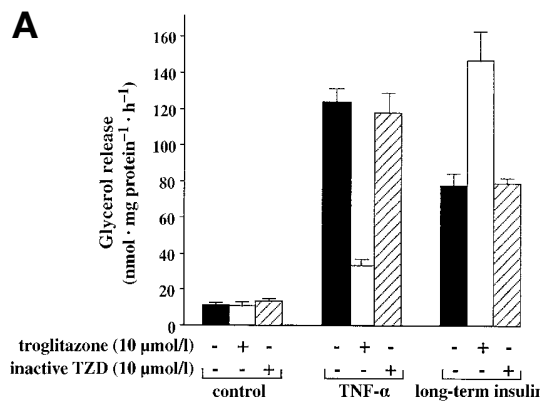

Fig. 4A, B. The effect of pretreatment and co-treatment with $10 \mu \mathrm{mol} / \mathrm{l}$ troglitazone $(\square)$ or $10 \mu \mathrm{mol} / \mathrm{l}$ inactive TZD glycerol (A) and NEFA release (B) from TNF- $\alpha$ and longterm insulin-treated 3T3-L1 adipocytes. Each value is the mean \pm SEM of three independent experiments done in triplicate

data suggest that the cellular mechanisms responsible for the increased glycerol release are distinct from those of TNF- $\alpha$. Collectively, these data suggest that long-term insulin exposure, while paradoxically increasing basal glycerol release, enhances NEFA reesterification.

Stimulation of lipolysis by long-term insulin, as measured by glycerol release is an unexpected finding because insulin is well known for its short-term anti-lipolytic actions. This finding is, however, in agreement with previous studies, which showed increased glycerol release after prolonged insulin treatment of isolated rat adipocytes [35, 36]. A recent study showed that the effect of long-term insulin depends on the presence of high glucose concentrations in the medium [36]. Yet, the role of the hexoseamine pathway in mediating this effect of long-term insulin was not supported as increased glycerol release occurred irrespective of the presence of glutamine in the medium. In our study, long-term exposure to insulin was done in the culture medium, which contained $25 \mathrm{mmol} / \mathrm{l}$ glucose. Yet, at the end of the incubation period, glycerol was collected for $1 \mathrm{~h}$ in a buffer without glucose. Thus it seems that extracellular glucose could be necessary as a priming factor, particularly under high glucose conditions but is not required for the actual metabolic flux responsible for glycerol generation. Collectively, these studies show the capacity of prolonged exposure to insulin, even at sub-nanomolar concentrations, to stimulate glycerol release as opposed to its short-term inhibitory effect on lipolysis.

In contrast to the effect on glycerol release, longterm exposure to insulin was not associated with increased NEFA concentrations in the medium, a finding consistent with a previous study [37]. Despite being the two end products of triacylglycerol breakdown, glycerol and NEFA released from adipocytes

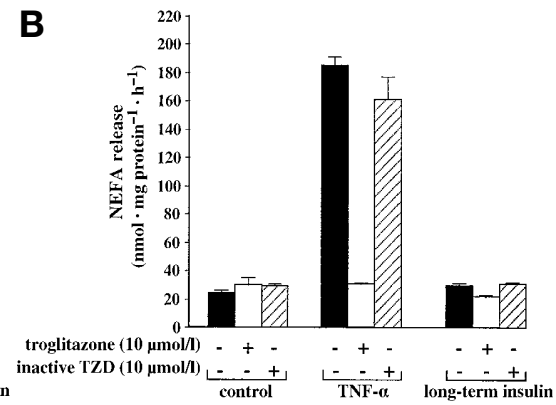

rarely reach the expected 1:3 molar ratio. Short-term insulin stimulation rapidly inhibits NEFA release from adipose tissue, through a combined inhibitory action on HSL and a stimulatory effect on NEFA reesterification $[14,21]$. Our study supports the possibility, that although long-term insulin stimulates glycerol release, acting opposite to its short-term anti-lipolytic action, the short-term insulin stimulatory effect on NEFA re-esterification is maintained under prolonged treatment. Because the anti-lipolytic effect of insulin and the stimulation of NEFA re-esterification have been shown to be downstream of PI 3-kinase [17, 21], they seem to diverge downstream of this point. These seemingly independent pathways to affect glycerol and NEFA release from adipocytes have been also shown in response to leptin [49], which was shown to stimulate glycerol but not NEFA release from isolated adipocytes. Whether leptin has a role in mediating the effects of longterm insulin on glycerol and NEFA release from adipose tissue is an intriguing possibility.

The role of long-term regulation of HSL activity, by prolonged exposure to insulin, in mediating the effects on glycerol and NEFA release is questionable. Although increased HSL activity after prolonged exposure of isolated adipocytes to insulin has been reported [35], our study does not support this notion, thus agreeing with a study reporting a lack of effect of insulin at the mRNA expression level of HSL [50]. In addition, it is noteworthy that the expression level of HSL frequently does not correlate with lipolysis rate. For example, our study and others' [27, 28] have shown that TNF- $\alpha$ stimulates lipolysis but decreases HSL expression. Similarly, in adipose tissue of obese patients an increased basal lipolysis rate has been shown but the HSL expression was lower compared with control subjects [8]. These discrepancies suggest several possibilities, including HSL translocation to the lipid droplet [51-53]. Consistent with this mechanism is a study which suggested that long-term insulin results in cellular redistribution of HSL and hence activation of lipolysis [36]. Alternatively, other lipases could be responsible for the effect of longterm insulin. This possibility is in line with the notion that HSL is not the only major regulator of adipocyte lipolysis as shown in HSL knockout mice [54]. Additionally, exposure of 3T3-L1 adipocytes to insulin for 
2 days resulted in increased glycerol release attributed to increased LPL activity [37]. Although insulin is known to increase LPL production in adipocytes as well as release to and activation in the vasculature [38], it is, however, not clear whether this enzyme can also function intracellularly on endogenous adipocyte triacylglycerols under the experimental conditions used (no serum as a source of Apo CII).

Tumour necrosis factor and insulin seem to use distinct cellular mechanisms in the activation of lipolysis. This is evident by our findings of distinct time courses, different effects on HSL protein content, unique modulations of the effect of acute lipolysis stimulation by isoproterenol and opposite response to coincubation with TZD. We found that Troglitazone treatment, although it greatly inhibited TNF- $\alpha$-mediated lipolysis, seemed to potentiate the effect of longterm insulin which is consistent with an "insulin sensitizer" mode of action. An example for such independent mechanisms would be, that TNF- $\alpha$ modulates HSL activity whereas long-term insulin regulates an alternative lipase. This would be consistent with our result that long-term insulin but not TNF- $\alpha$ has an additive effect on glycerol release induced by isoproterenol. In summary, long-term insulin treatment of 3T3-L1 adipocytes stimulates lipolysis but enhances NEFA re-esterification, acting differently from either its short-term effects or from TNF- $\alpha$.

Acknowledgements. This study was supported by a grant from the Israeli Academy of Sciences and Humanities (to A. Rudich) and by the U.S. Department of Agriculture (3K06510), Grant DK50647 from National Institutes of Health (NIH), American Diabetes Association and Grant P30 DK34928 from NIH (to A.S. Greenberg). In addition, we would like to thank Drs. A. Saltiel and H. Camp (Parke-Davis) for the troglitazone and inactive TZD.

\section{References}

1. Boden G (1997) Role of fatty acids in the pathogenesis of insulin resistance and NIDDM. Diabetes 46: 3-10

2. Guo Z, Jensen MD (1999) Blood glycerol is an important precursor for intramuscular triacylglycerol synthesis. J Biol Chem 274: 23702-23706

3. Griffin ME, Marcucci MJ, Cline GW et al. (1999) Free fatty acid-induced insulin resistance is associated with activation of protein kinase $C$ theta and alterations in the insulin signaling cascade. Diabetes 48: 1270-1274

4. Mason TM, Goh T, Tchipashvili V et al. (1999) Prolonged elevation of plasma free fatty acids desensitizes the insulin secretory response to glucose in vivo in rats. Diabetes 48 : 524-530

5. Nurjhan N, Consoli A, Gerich J (1992) Increased lipolysis and its consequences on gluconeogenesis in non-insulin-dependent diabetes mellitus. J Clin Invest 89: 169-175

6. Chen X, Iqbal N, Boden G (1999) The effects of free fatty acids on gluconeogenesis and glycogenolysis in normal subjects. J Clin Invest 103: 365-372

7. Perseghin G, Scifo P, De Cobelli F et al. (1999) Intramyocellular triglyceride content is a determinant of in vivo in- sulin resistance in humans: a $1 \mathrm{H}-13 \mathrm{C}$ nuclear magnetic resonance spectroscopy assessment in offspring of Type II diabetic parents. Diabetes 48: 1600-1606

8. Large V, Reynisdottir S, Langin D et al. (1999) Decreased expression and function of adipocyte hormone-sensitive lipase in subcutaneous fat cells of obese subjects. J Lipid Res 40: 2059-2066

9. Arner P (1999) Catecholamine-induced lipolysis in obesity. Int J Obes Relat Disord [Suppl 1]: 10-13

10. Londos C, Honnor RC, Dhillon GS (1985) cAMP-dependent protein kinase and lipolysis in rat adipocytes. III. Multiple modes of insulin regulation of lipolysis and regulation of insulin responses by adenylate cyclase regulators. J Biol Chem 260: 15139-15145

11. Stralfors P, Bjorgell P, Belfrage P (1984) Hormonal regulation of hormone-sensitive lipase in intact adipocytes: identification of phosphorylated sites and effects on the phosphorylation by lipolytic hormones and insulin. Proc Natl Acad Sci USA 81: 3317-3321

12. Anthonsen MW, Ronnstrand L, Wernstedt C, Degerman E, Holm C (1998) Identification of novel phosphorylation sites in hormone-sensitive lipase that are phosphorylated in response to isoproterenol and govern activation properties in vitro. J Biol Chem 273: 215-221

13. Holm C, Langin D, Manganiello V, Belfrage P, Degerman E (1997) Regulation of hormone-sensitive lipase activity in adipose tissue. Methods-Enzymol 286: 45-67

14. Londos C (1996) Hormone-sensitive lipase and the control of lipolysis in adipocytes. In: LeRoith D, Tailor SI, Olefsky JM (eds) Lippicott-Raven, Philadelphia, pp 223-227

15. Coppack SW, Jensen MD, Miles JM (1994) In vivo regulation of lipolysis in humans. J Lipid Res 35: 177-193

16. Smith CJ, Vasta V, Degerman E, Belfrage P, Manganiello VC (1991) Hormone-sensitive cyclic GMP-inhibited cyclic AMP phosphodiesterase in rat adipocytes. Regulation of insulin- and cAMP-dependent activation by phosphorylation. J Biol Chem 266: 13385-13390

17. Okada T, Kawano Y, Sakakibara T, Hazeki O, Ui M (1994) Essential role of PI 3-kinase in insulin-induced glucose transport and antilipolysis in rat adipocytes. J Biol Chem 269: 3568-3573

18. Degerman E, Belfrage P, Manganiello VC (1997) Structure, localization, and regulation of cGMP-inhibited phosphodiesterase (PDE3). J Biol Chem 272: 6823-6826

19. Degerman E, Landstrm TR, Wijkander J et al. (1998) Phosphorylation and activation of hormone-sensitive adipocyte phosphodiesterase type 3B. Methods 14: 43-53

20. Campbell PJ, Carlson MG, Nurjhan N (1994) Fat metabolism in human obesity. Am J Physiol 266: E600-E6005

21. Zierath JR, Livingston JN, Thorne A et al. (1998) Regional difference in insulin inhibition of non-esterified fatty acid release from human adipocytes: relation to insulin receptor phosphorylation and intracellular signalling through the insulin receptor substrate-1 pathway. Diabetologia 41: 1343-1354

22. Van Harmelen V, Reynisdottir S, Cianflone K et al. (1999) Mechanisms involved in the regulation of free fatty acid release from isolated human fat cells by acylation-stimulating protein and insulin. J Biol Chem 274: 18243-18251

23. Sewter CP, Digby JE, Blows F, Prins J, O'Rahilly S (1999) Regulation of Tumor Necrosis Factor-alpha release from human adipose tissue in vitro. J Endocrinol 163: 33-38

24. Hotamisligil G, Shargill N, Speigelman B (1993) Adipose expression of Tumor Necrosis Factor alpha: direct role in obesity -linked insulin resistance. Science 259: 87-91

25. Feingold KR, Doerrler W, Dinarello CA, Fiers W, Grunfeld C (1992) Stimulation of lipolysis in cultured fat cells 
by tumor necrosis factor, interleukin-1, and the interferons is blocked by inhibition of prostaglandin synthesis. Endocrinology 130: 10-16

26. Hauner H, Petruschke T, Russ M, Rohrig K, Eckel J (1995) Effects of tumour necrosis factor alpha (TNF alpha) on glucose transport and lipid metabolism of newly-differentiated human fat cells in cell culture. Diabetologia 38: 764-771

27. Sumida M, Sekiya K, Okuda H, Tanaka Y, Shiosaka T (1990) Inhibitory effect of tumor necrosis factor on gene expression of hormone sensitive lipase in 3T3-L1 adipocytes. J Biochem (Tokyo) 107: 1-2

28. Souza SC, Yamamoto MT, Franciosa MD, Lien P, Greenberg AS (1998) BRL 49653 blocks the lipolytic actions of tumor necrosis factor-alpha: a potential new insulin-sensitizing mechanism for thiazolidinediones. Diabetes 47: 691-695

29. Gasic S, Tian B, Green A (1999) Tumor necrosis factor alpha stimulates lipolysis in adipocytes by decreasing Gi protein concentrations. J Biol Chem 274: 6770-6775

30. Souza SC, de Vargas LM, Yamamoto MT et al. (1998) Overexpression of perilipin A and B blocks the ability of tumor necrosis factor alpha to increase lipolysis in 3T3-L1 adipocytes. J Biol Chem 273: 24665-24669

31. Greenberg AS, Egan JJ, Wek SA, Garty NB, Blanchette Mackie EJ, Londos C (1991) Perilipin, a major hormonally regulated adipocyte-specific phosphoprotein associated with the periphery of lipid storage droplets. J Biol Chem 266: 11341-11346

32. Blanchette Mackie EJ, Dwyer NK, Barber T et al. (1995) Perilipin is located on the surface layer of intracellular lipid droplets in adipocytes. J Lipid Res 36: 1211-1226

33. Saltiel AR, Olefsky JM (1996) Thiazolidinediones in the treatment of insulin resistance and type II diabetes. Diabetes 45: 1661-1669

34. Rahn-Landsrom T, Mei J, Karlsson M, Manganiello V, Degerman E (2000) Down-regulation of cyclic-nucleotide phosphodiesterase 3B in 3T3-L1 adipocytes induced by tumour necrosis factor a and cAMP. Biochem J 346: 337-343

35. Kang ES, Betts D, Fain JN, Bahouth SW, Myers LK (1993) Chronic exposure of rat fat cells to insulin enhances lipolysis and activation of partially purified hormone-sensitive lipase. Diabetes 42: 1415-1424

36. Botion LM, Green A (1999) Long-term regulation of lipolysis and hormone-sensitive lipase by insulin and glucose. Diabetes 48: 1691-1697

37. Chernick SS, Spooner PM, Garrison MM, Scow RO (1986) Effect of epinephrine and other lipolytic agents on intracellular lipolysis and lipoprotein lipase activity in 3T3-L1 adipocytes. J Lipid Res 27: 286-294

38. Fielding BA, Frayn KN (1998) Lipoprotein lipase and the disposition of dietary fatty acids. Br J Nutr 80: 495-502

39. Rudich A, Tirosh A, Potashnik R, Hemi R, Kanety H, Bashan N (1998) Prolonged oxidative stress impiars insulininduced GLUT4 translocation in 3T3-L1 adipocytes. Diabetes 47: 1562-1569

40. Tirosh A, Potashnik R, Bashan N, Rudich A (1999) Oxidative stress disrupts insulin-induced cellular redistribution of insulin receptor substrate-1 and phosphatidylinositol 3-kinase in 3T3-L1 adipocytes. J Biol Chem 274: 10595-10602

41. Rudich A, Kozlovsky N, Potashnik R, Bahan N (1997) Oxidant stress reduces insulin responsiveness in 3T3-L1 adipocytes. Am J Physiol 272: E935-E940

42. Wieland O (1965) Methods of enzymatic analysis. In: Bergmeyer HU (ed) Academic Press, New York and London, pp 211-214

43. Vaughan M (1961) The production and release of glycerol by adipse tissue incubated in-vitro. J Biol Chem 237: 3354-3358

44. Steinberg D, Vaughan M (1965) Handbook of Physiology. American Physiological Society, Bethesda, pp 335-347

45. Flores Riveros JR, McLenithan JC, Ezaki O, Lane MD (1993) Insulin down-regulates expression of the insulin-responsive glucose transporter (GLUT4) gene: effects on transcription and mRNA turnover. Proc Natl Acad Sci USA 90: 512-516

46. Ricort JM, Tanti JF, Van Obberghen E, Le Marchand Brustel Y (1995) Alterations in insulin signalling pathway induced by prolonged insulin treatment of 3T3-L1 adipocytes. Diabetologia 38: 1148-1156

47. Weiland M, Bahr F, Hohne M, Schurmann A, Ziehm D, Joost HG (1991) The signaling potential of the receptors for insulin and insulin-like growth factor I (IGF-I) in 3T3L1 adipocytes: comparison of glucose transport activity, induction of oncogene c-fos, glucose transporter mRNA, and DNA-synthesis. J Cell Physiol 149: 428-435

48. Thomson MJ, Williams MG, Frost SC (1997) Development of insulin resistance in 3T3-L1 adipocytes. J Biol Chem 272: 7759-7764

49. Wang MY, Lee Y, Unger RH (1999) Novel form of lipolysis induced by leptin. J Biol Chem 274: 17541-17544

50. Plee Gautier E, Grober J, Duplus E, Langin D, Forest C (1996) Inhibition of hormone-sensitive lipase gene expression by cAMP and phorbol esters in 3T3-F442A and BFC1 adipocytes. Biochem J 318: 1057-1063

51. Egan JJ, Greenberg AS, Chang MK, Wek SA, Moos MC Jr, Londos C (1992) Mechanism of hormone-stimulated lipolysis in adipocytes: translocation of hormone-sensitive lipase to the lipid storage droplet. Proc Natl Acad Sci USA 89: 8537-8541

52. Clifford GM, Londos C, Kraemer FB, Vernon RG, Yeaman SJ (2000) Translocation of hormone-sensitive lipase and perilipin upon lipolytic stimulation of rat adipocytes. J Biol Chem 275: 5011-5015

53. Brasaemle DL, Levin DM, Adler-Eailes DC, Londos C (2000) The lipolytic stimulation of 3T3-L1 adipocytes promotes the translocation of hormone-sensitive lipase to the surfaces of lipid storage droplets. Biochim Biophys Acta 1483: 251-262

54. Osuga J, Ishibashi S, Oka T et al. (2000) Targeted disruption of hormone-sensitive lipase results in male infertility and adipocyte hypertrophy, but no obesity. Proc Natl Acad Sci USA 97: 787-792 